\title{
YM155 Inhibits Neuroblastoma Cell Migration and Survival in Vitro and Tumor Growth and Metastatic Burden in a Pre-Clinical Model
}

\author{
Heather M. Calderone ${ }^{1,2}$, Akshita Dutta ${ }^{1,2}$, Lauren Smith1, Alexandra Eckardt', Ping Zhao',2, \\ Giselle Saulnier Sholler ${ }^{2,3^{*}}$ \\ ${ }^{1}$ Laboratory for Translational Neuroblastoma Research, Van Andel Research Institute, Grand Rapids, USA \\ ${ }^{2}$ Pediatric Oncology Translational Research Program, Helen DeVos Children's Hospital, Grand Rapids, USA \\ ${ }^{3}$ Michigan State University College of Medicine, Grand Rapids, USA \\ Email: * Giselle.SaulnierSholler@helendevoschildrens.org
}

Received 26 August 2014; revised 20 September 2014; accepted 18 October 2014

Copyright (C) 2014 by authors and Scientific Research Publishing Inc.

This work is licensed under the Creative Commons Attribution International License (CC BY).

http://creativecommons.org/licenses/by/4.0/

(c) (i) Open Access

\begin{abstract}
Background: Neuroblastoma exhibits a high incidence of chromosomal translocations, the most common being the gain of a portion of the long arm of chromosome 17. This region includes the gene BIRC5/survivin, which is highly upregulated in neuroblastoma and correlates with poor prognosis. Survivin is a member of the inhibitor of apoptosis family of proteins and is involved in tumor cell survival and migration. YM155 is a small molecule inhibitor of survivin transcription and has shown efficacy in several cancer model systems both in vitro and in vivo. Procedure: Cells were treated with YM155 and effects on migration, invasion, and apoptosis signaling were investigated in vitro. Tumor burden was assessed in xenografted mice by measuring tumor volume and liver metastases. Results: Treatment with YM155 caused a dose-dependent decrease in survivin expression and induction of apoptosis. Lower concentrations of YM155 reduced cell migration and invasion by $15 \%$ - $50 \%$ which varied by cell line. In a xenograft model, YM155 treatment inhibited tumor growth by $25 \%-70 \%$, reduced metastatic burden in the liver by $50 \%$, and prolonged animal survival. Conclusion: The data suggest YM155 as a possible therapeutic agent for metastatic neuroblastoma.
\end{abstract}

\section{Keywords}

Neuroblastoma, YM155, Survivin, Metastasis, Apoptosis

\footnotetext{
${ }^{*}$ Corresponding author.
}

How to cite this paper: Calderone, H.M., Dutta, A., Smith, L., Eckardt, A., Zhao, P. and Sholler, G.S. (2014) YM155 Inhibits Neuroblastoma Cell Migration and Survival in Vitro and Tumor Growth and Metastatic Burden in a Pre-Clinical Model. Journal of Cancer Therapy, 5, 1289-1302. http://dx.doi.org/10.4236/jct.2014.513129 


\section{Introduction}

Neuroblastoma originates from neural crest cells and can arise nearly anywhere along the sympathetic nervous system [1] [2]. As the most common pediatric extracranial solid tumor, neuroblastoma accounts for $7 \%$ of childhood cancers in the US [3] and 15\% of pediatric cancer deaths [1] [4]. Despite aggressive multimodal therapy, including high-dose chemotherapy, hematopoietic stem cell transplantation, and maintenance with retinoic acid and immunotherapy, little progress has been made in survival among the high-risk group. High-risk neuroblastoma is characterized by segmental chromosomal aberrations and metastasis to bone or bone marrow [5]. Fifty to sixty percent of high-risk neuroblastoma patients will relapse with metastases [5]. This illustrates the need for therapies that target tumor growth as well as metastasis [6].

Genetic changes in the more aggressive forms of neuroblastoma are often segmental chromosome aberrations [2]. A recent study determines that among 8800 tumors the most common segmental chromosomal aberration is gain of $17 q$, occurring in $48 \%$ of neuroblastomas [7]. One gene of interest mapped to this region is baculoviral inhibitor of apoptosis repeat-containing 5 (BIRC5)/survivin, which is overexpressed in many cancers including neuroblastoma [8] [9]. Gain of 17q and overexpression of survivin also correlates with MYCN amplification [1] [2] [8]. As gene amplification tends to drive neuroblastoma, there is a need for novel therapies that can modulate expression of these driver genes.

Sepantronium bromide (YM155) is a novel small molecule that inhibits survivin promoter activity by interfering with the IF3/p54 ${ }^{\text {nff }}$ transcription factor complex [10] and binding of the Sp1 transcription factor to the survivin core promoter [11], resulting in decreased survivin expression [10] [11]. YM155 inhibits proliferation in vitro and induces tumor regression in vivo in multiple cancer cell lines [12]. Additionally, dose and time dependent induction of cell death was observed in vitro [13]. Recent studies indicate that YM155 also inhibits expression of the Bcl-2 family member, Mcl-1; however, whether the effects are on mRNA or protein is cell typespecific [14]-[16]. Mcl-1 is upregulated in neuroblastoma and is a key mediator of chemoresistance [1] [17]. Therefore, inhibition of Mcl-1 by YM155 may contribute to apoptosis in neuroblastoma cells. Indeed, most established neuroblastoma cell lines are sensitive to YM155 at low nanomolar concentrations in vitro, which is partially rescued by exogenous expression of survivin [18].

Survivin is a member of the inhibitor of apoptosis (IAP) family of proteins. It is highly expressed during embryonic development where it is involved in proliferation, migration, and apoptosis [19] [20]. Survivin is extensively downregulated in differentiated tissues, but is highly upregulated in many cancers [19]. Survivin inhibits apoptosis by inhibiting the release of SMAC/DIABLO and apoptosis inducing factor from the mitochondria to prevent signaling and transcription for apoptosis [19]. When exported from the mitochondria, survivin interacts with and stabilizes XIAP to inhibit caspase cascades [9].

Recent studies have also indicated that survivin is associated with increased migration of cancer cells [20] [21], which is independent of survivin-mediated survival signaling [20]. Survivin mediates migration and invasion through AKT activation and upregulation of $\alpha 5$-integrin in melanoma [21] and through NF- $\kappa$ B-mediated upregulation of fibronectin and $\beta 1$-integrin to induce signaling through focal adhesion kinase in adenocarcinoma [20]. High levels of survivin are also correlated with metastatic disease in Ewing's sarcoma [22] and malignant peripheral nerve sheath tumors [23].

In neuroblastoma, high survivin expression correlates with MYCN amplification, high-risk group [24], recurrence, and decreased overall survival [25]. Inhibition of survivin expression in neuroblastoma cells increases apoptosis [26] and sensitization to chemotherapy [27]. Additionally, survivin knockdown reduced migration of neuroblastoma cells [28].

The nearly cancer-specific expression in many cancers combined with the vast roles it plays in tumor progression, makes survivin an attractive target. Indeed, YM155 has been studied in a variety of cancer models [10]-[16] [18] [29]-[37] and has been studied in clinical trials for adult cancers [38] [39]. In this study, we investigate this small-molecule survivin suppressant on neuroblastoma cell migration and invasion in vitro as well as tumor growth and metastasis in vivo. The overall goal of this work is to establish YM155 as an effective treatment for metastatic neuroblastoma.

\section{Methods}

\subsection{Cell Culture}

Cells were maintained in RPMI $+10 \%$ FBS $+1 \%$ Penicillin/Streptomycin (Invitrogen) in a $37^{\circ} \mathrm{C}$ humidified 
chamber with $5 \% \mathrm{CO}_{2}$. Cell lines were authenticated by short tandem repeats (DNA Diagnostics Center).

\subsection{Survivin Suppressor}

YM155 (provided by Astellas Pharma) was dissolved in DMSO (10 mM). Aliquots were thawed and diluted in cell culture medium for in vitro assays or in saline for xenograft studies on the day of treatment.

\subsection{Whole Genome Expression}

Cells were plated in duplicate or triplicate overnight in growth media and then collected, or treated with fresh media $\pm 250 \mathrm{nM}$ YM155 then collected at 6 and 12 hours (hr). Expression data were evaluated by cDNA microarray, U133 Plus 2.0 (Clinical Reference Laboratory). Untreated cell lines were compared to a 45-sample wholebody reference set as is used in pediatric personalized medicine clinical trials by the Neuroblastoma and Medulloblastoma Translational Research Consortium. Partek ${ }^{\circledR}$ Genomics Suite ${ }^{\mathrm{TM}}$ and the R environment were used for microarray analysis. Gene chip data were normalized and probe set expression matrix were calculated using the Robust-multi array method [40]. Differential Expression statistics were analyzed between sample groups designated as normal and neuroblastoma cell line.

\subsection{Quantitative RT-PCR}

Cells were plated overnight in growth medium and then treated with 50 or 250 nM YM155 for 6 and 12 hr. Lysates were collected using Trizol (Invitrogen), RNA extracted using BCP (Sigma) and the RNeasy clean-up kit (Qiagen), and cDNA made using High Capacity cDNA (Applied Biosystems). DNA was extracted from two areas of fixed liver tissue from xenografted mice using the QIAamp DNA FFPE tissue kit (Qiagen). All reactions were run in triplicate using 30 - 100 ng cDNA or 100 ng DNA per reaction, Taqman Fast Advanced Master Mix (Applied Biosystems) or Sso Advanced supermix (Bio-Rad), BIRC5, Mcl-1, and $\beta$-actin Taqman assays (Applied Biosystems) or primers (Invitrogen) for human Alu (forward: 5'-ctgtttgtggcttgttcag-3', reverse: 5'-aggaaaccttccctcctcta-3') and mouse GAPDH (forward: 5'-ttggttgagaagcagaaaca-3', reverse: 5'-cacacagtcaagttcccaaa-3').

\subsection{Western Blot}

Cells were plated in 6-well plates overnight in growth medium, then treated with 12.5 - 1000 nM YM155 for 24 or $48 \mathrm{hr}$. Cell lysates were collected with RIPA buffer, protein concentration measured, proteins separated by SDS-PAGE, and blotted as previously described [41]. Primary antibodies include survivin (R\&D Systems), cleaved Caspase-3, Caspase-3, cleaved PARP, PARP, Mcl-1 (Cell Signaling), actin (Cell Signaling or Santa Cruz), and beta tubulin (produced in house). Secondary antibodies were purchased from Licor. Blots were imaged using an Odyssey infrared scanner (Licor). Quantitation was performed using Image Studio software (Licor) and reflects triplicate blots.

\subsection{Cell Viability}

Cells were plated 4000 - 7000 cells per well in 96-well plates overnight, then treated with 4 - $4000 \mathrm{nM}$ YM155 as indicated for 48 or $72 \mathrm{hr}$. Viability was determined by Calcein AM as previously described [41] and reflect three experiments.

\subsection{Wound Assay}

Cells were plated overnight in growth media $2.5 \times 10^{5}$ cells per well in glass-bottom plates (Grenier Bio-One). Wounds were made using a pipette tip. Cells were washed with media and media were replaced \pm YM155. At least ten fields per wound were imaged every $15 \mathrm{~min}$ for $20 \mathrm{hr}$ using a Nikon Eclipse Ti microscope with a $\mathrm{CO}_{2}$ controlled, humidified chamber. Migration distance measured using Nikon Elements software.

\subsection{Transwell Migration and Invasion Assays}

Sub-confluent cells were serum starved for $2 \mathrm{hr}$ and Bio-coat inserts were rehydrated for $2 \mathrm{hr}$ in serum free (SF)-media. Cells were suspended in SF-medium \pm 10 or $20 \mathrm{nM}$ YM155 and seeded in triplicate onto transwell 
filters, $1 \times 10^{5}$ cells per well in 24-well plates for migration and $5 \times 10^{5}$ in 6-well Bio-coat plates for invasion (BD biosciences). Cells were allowed to settle for 20 - 30 min then lower wells were filled with medium containing $10 \%$ FBS as a chemoattractant \pm YM155 as indicated. After 20 (migration) or 48 hr (invasion), cells on the bottom of the filters were trypsinized, collected, pelleted, washed with PBS, and frozen. Cell number was determined by CyQUANT (Molecular Probes) using a standard curve for each cell line created on the day of plating. Results reflect percent of untreated controls and the average of three experiments.

\subsection{Xenograft}

Cells were suspended in Matrigel (BD Biosciences) and injected subcutaneously into the flanks of five-week-old female nude mice $\left(10^{7}\right.$ cells in $0.1 \mathrm{~mL}$ Matrigel per mouse). When tumor volumes reached $100 \mathrm{~mm}^{3}$ (length $\times$ width $\times$ depth $\times 0.52$ ), YM155 was administered by 7-day continuous infusion using Alzet osmotic pumps (1007D, Durect Corporation) according to manufacturer's instructions. Pumps were subcutaneously implanted into the backs of the mice and removed after ten days. Tumors were measured twice weekly by caliper. Animals were sacrificed when control animal tumors exceeded $3.0 \mathrm{~cm}^{3}$. For survival studies, animals were sacrificed individually when each tumor reached $3.0 \mathrm{~cm}^{3}$. Studies were approved by the Institutional Animal Care and Use Committee at the Van Andel Research Institute.

\subsection{Statistics}

Statistical analyses were performed using GraphPad or R software. Welch's t-test was used for comparisons of RNA expression in cell lines versus normal tissues. For in vivo survival curves, a log-rank test was used. Student's t-test was used for all other comparisons. All comparisons were considered significant at $\mathrm{p} \leq 0.05$.

\section{Results}

\subsection{BIRC5/Survivin Expression in Neuroblastoma}

Expression levels of survivin in neuroblastoma cell lines were determined by microarray and compared to a whole-body reference set (Table 1). Values shown indicate fold change over the expression in normal tissues. BIRC5/survivin expression in the four neuroblastoma cell lines tested is 37 - 64-fold higher than in normal tissue. It has been reported that amplification of MYCN is correlated with gain of 17q [1] [2] [8]. Our data confirm that cell lines with MYCN amplification also had the highest survivin expression (Table 1).

\subsection{YM155 Inhibits Survivin Expression and Cell Viability in Neuroblastoma Cell Lines}

Inhibition of survivin expression was confirmed by western blot following $48 \mathrm{hr}$ exposure to YM155. Figure 1(a) shows that YM155 inhibits expression of survivin in all four cell lines. Quantification (Figure 1(b)) indicates that the effects were dose-dependent. Excessive cell death among SMS-KNCR cells was observed at high concentrations of YM155 (data not shown); therefore, these cells were treated with lower concentrations than the other cell lines here and throughout the rest of this study. To confirm that YM155 inhibits transcription of survivin in neuroblastoma cells, quantitative RT-PCR was used to measure the levels of survivin transcript at 6 hr and $12 \mathrm{hr}$ of treatment with $250 \mathrm{nM}$ YM155 (50 nM for SMS-KCNR [Figure 1(c)]). Indeed, expression of survivin was reduced. However, the changes in expression were cell line-dependent and did not correlate with

Table 1. Gene expression in neuroblastoma cell lines. Expression of survivin is upregulated in neuroblastoma cell lines. Two MYCN amplified and non-amplified cell lines were used in this study. Fold change and p-values were calculated by comparing expression in neuroblastoma cell lines to a 45 -sample whole-body reference set.

\begin{tabular}{ccccccc}
\hline & \multicolumn{2}{c}{ BIRC5/survivin } & \multicolumn{2}{c}{ MYCN } & \multicolumn{2}{c}{ ABCB1 } \\
\cline { 2 - 7 } & Fold change & p-value & Fold change & p-value & Fold change & p-value \\
BE(2)C & 64.0609 & $4.45 \mathrm{E}-8$ & 379.391 & $1.57 \mathrm{E}-26$ & 9.19534 & 0.000461 \\
CHLA90 & 37.9506 & $8.31 \mathrm{E}-7$ & 4.07487 & $1.21 \mathrm{E}-5$ & 2.26204 & 0.174805 \\
SH-SY5Y & 51.4153 & $1.53 \mathrm{E}-7$ & 6.00858 & $1.01 \mathrm{E}-7$ & 4.0512 & 0.022177 \\
SMS-KCNR & 58.7294 & $7.25 \mathrm{E}-8$ & 363.059 & $2.22 \mathrm{E}-26$ & -5.7772 & 0.004676 \\
\hline
\end{tabular}




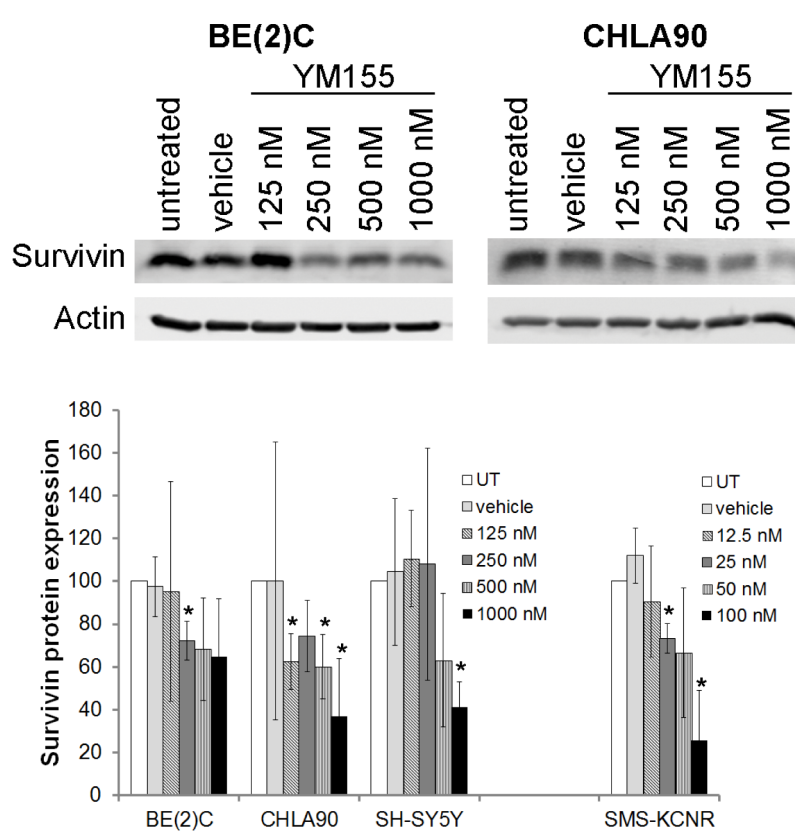

(b)

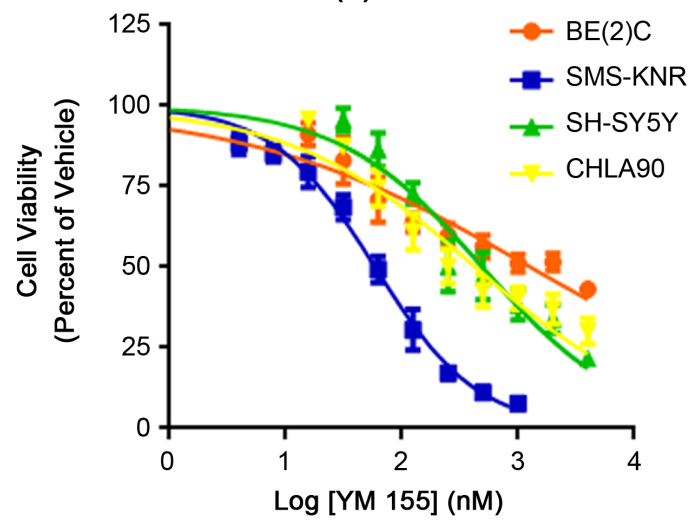

(d)

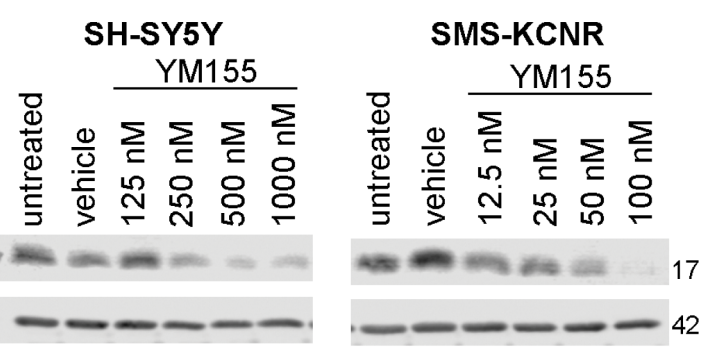

(a)

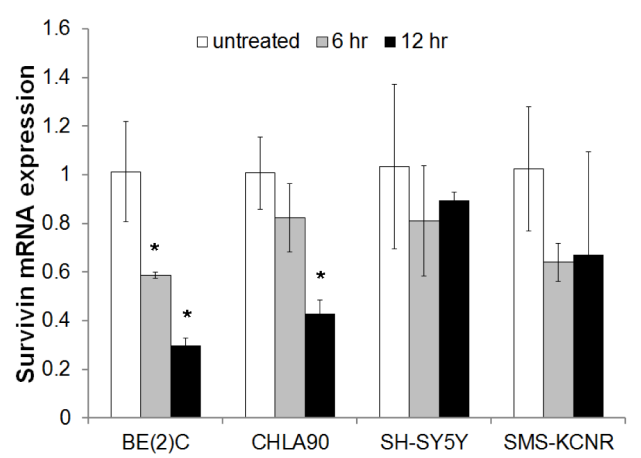

(c)

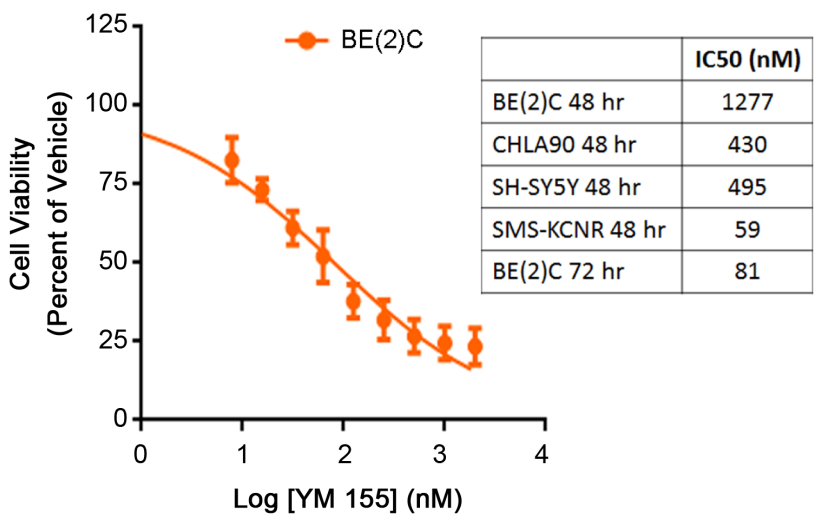

(e)

Figure 1. YM155 inhibits survivin expression in neuroblastoma cell lines. (a) Neuroblastoma cells were exposed to increasing concentrations of YM155 for $48 \mathrm{hr}$ and cell lysates were subject to western blot; (b) Quantitation of westerns shows that survivin expression decreased in a dose-dependent manner in all four cell lines; (c) qRT-PCR confirms the reduction in survivin transcript when cells were treated with YM155. BE(2)C, CHLA90, and SH-SY5Y were treated with 250 nM YM155 and SMS-KNCR were treated with $50 \mathrm{nM}$ for times indicated. Data reflect fold change vs. untreated cells at the same time point; (d) and (e) Neuroblastoma cells were treated with increasing concentrations of YM155 for (d) 48 or (e) 72 hr. Cell viability was determined by calcein $\mathrm{AM}$. $\mathrm{IC}_{50}$ values for each cell line are represented to the right. $\mathrm{n}=3$ experiments. Data is presented as percent of untreated cells. Representative blots are shown, quantitation represents $n=3$ experiments. ${ }^{*}$ Indicates significantly different than untreated controls $\mathrm{p} \leq 0.023$.

the overall level of survivin expression as indicated in Table 1.

Cell viability was measured following 48 hr YM155 treatment. Sensitivity varied by cell line and also did not correlate with the level of expression of survivin (Table 1). The SMS-KCNR cell line was found to be the most sensitive, followed by CHLA90 and SH-SY5Y. BE(2)C cells were the most resistant with an IC 50 of $1277 \mathrm{nM}$ at $48 \mathrm{hr}$ (Figure 1(d)); however, longer exposure to YM155 (Figure 1(e)) reduced the IC 50 markedly to $81 \mathrm{nM}$ at $72 \mathrm{hr}$.

\subsection{Treatment with Low-Dose YM155 Inhibits Cell Migration and Invasion in Vitro}

Effects of YM155 on cell migration were assessed over 20 hrs. For all migration and invasion experiments, cells 
were treated with lower concentrations of YM155 to reduce confounding effects on cell proliferation. BE(2)C cells were plated in a confluent monolayer and subject to a wound assay $\pm 20 \mathrm{nM}$ YM155. By $20 \mathrm{hr}$, untreated cells had migrated further into the wound area than YM155-treated cells (Figure 2(a) and Figure S1(a) and Figure S1(b)). Distance migrated was measured at 30 min intervals over $20 \mathrm{hr}$. Results reflect the distance migrated as a percent of the maximum migration (average distance migrated by untreated cells at $20 \mathrm{hr}$ ). Treatment with YM155 inhibited the distance migrated of BE(2)C cells by 32\% compared to untreated cells (Figure 2(b)). Cell viability was not affected at this dose even at $48 \mathrm{hr}$ (Figure 2(f)) and YM155 did not induce apoptotic signaling at $24 \mathrm{hr}$ except at the high doses (Figure S2).

Because SMS-KCNR cells do not form a monolayer, which is necessary for a wound assay, migration was assessed by transwell assay. Cells were plated in transwell plates $\pm 20 \mathrm{nM}$ YM155. Migrating cells were collected and cell number determined by Cyquant. Results reflect percent of untreated cells. Cells were also plated in triplicate in 24-well plates $\pm 20 \mathrm{nM}$ YM155 to determine effects on proliferation at the same time-point. Low-dose YM155 reduced the number of cells migrating by 15\% (Figure 2(c)), but did not significantly affect proliferation (Figure 2(d)).

Cellular invasion was assessed by Matrigel invasion assay. Invading cells were collected at $48 \mathrm{hr}$. Results
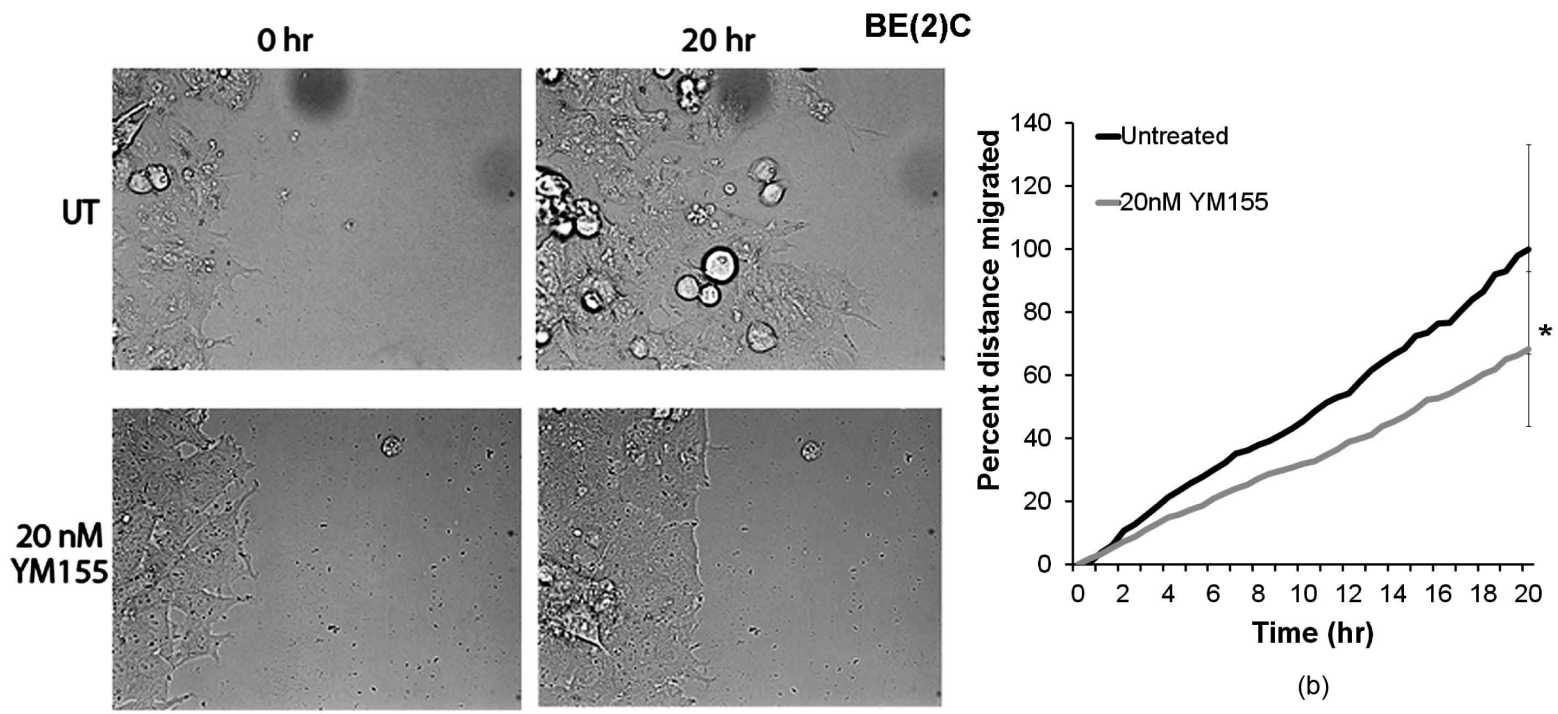

(a)

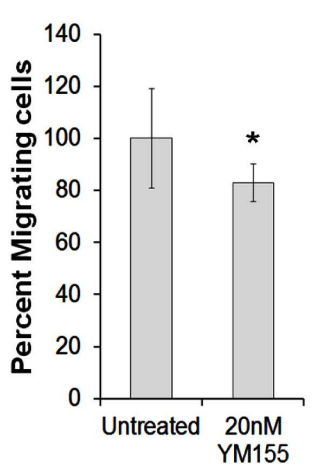

(c)

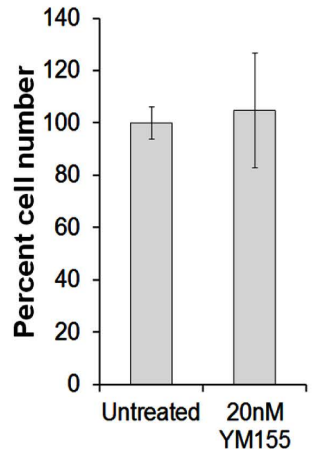

(d)

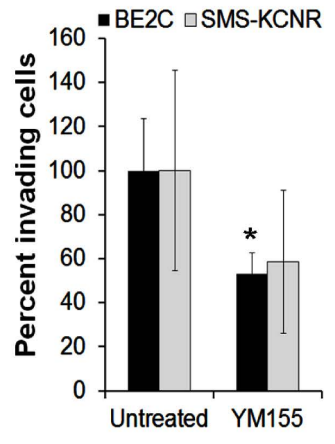

(e)

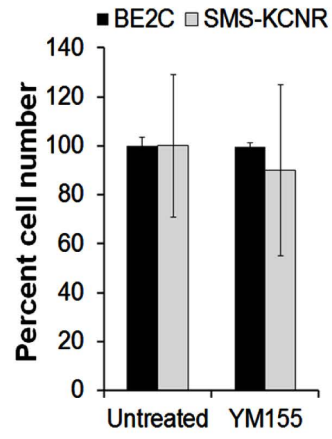

(f)

Figure 2. YM155 inhibits cell migration and invasion in vitro. Cells were treated with low concentrations of YM155. (a) and (b) $\mathrm{BE}(2) \mathrm{C}$ cells were subject to a wound assay. (a) Start and end point images illustrate that YM155 reduced migration into the wound area; (b) Distance migrated was measured at 3 locations across each wound at 30 minute intervals over $20 \mathrm{hr}$. For simplification, only the error bars for the $20 \mathrm{hr}$ time point are shown; (c) $20 \mathrm{nM}$ YM155 reduced migration of SMS-KCNR cells by $17 \%$, but did not affect proliferation of SMS-KCNR cells; (d) Invasion of BE(2)C cells was reduced by $47 \%$ with 20 nM YM155 treatment over $48 \mathrm{hr}$, but proliferation was not affected. *Indicates significantly less than untreated cells, p < 0.05 . 
reflect percent of untreated cells. YM155 inhibited the number of invading BE(2)C cells by nearly 50\% (Figure 2(e)), but did not affect proliferation over this time course (Figure 2(f)). To assess invasion of SMS-KCNR cells, the concentration of YM155 was decreased to $10 \mathrm{nM}$ to avoid affecting cell proliferation over the longer time course (Figure 2(f)). In 48 hr, SMS-KCNR cells demonstrated a slight, but non-significant, decrease in invasion with YM155 treatment (Figure 2(e)).

\subsection{YM155 Induces Signaling for Apoptosis}

Western blot analysis following $48 \mathrm{hr}$ treatment with increasing concentrations of YM155 confirm increased apoptotic signaling. Blots were probed for cleaved caspase-3 and for cleaved-Poly ADP Ribose Polymerase (PARP) (Figure 3(a)) to indicate the increased incidence of programmed cell death induced by YM155 in each cell line.

YM155 has also been reported to inhibit expression of Mcl-1 in a panel of cancer cell lines [14], but this has not been shown in neuroblastoma cell lines. Microarray analysis of BE(2)C cells exposed to YM155 for $12 \mathrm{hr}$ showed a small but significant decrease in Mcl-1 expression (1.21-fold decrease $\mathrm{p}=0.008$ ). Western blot analysis

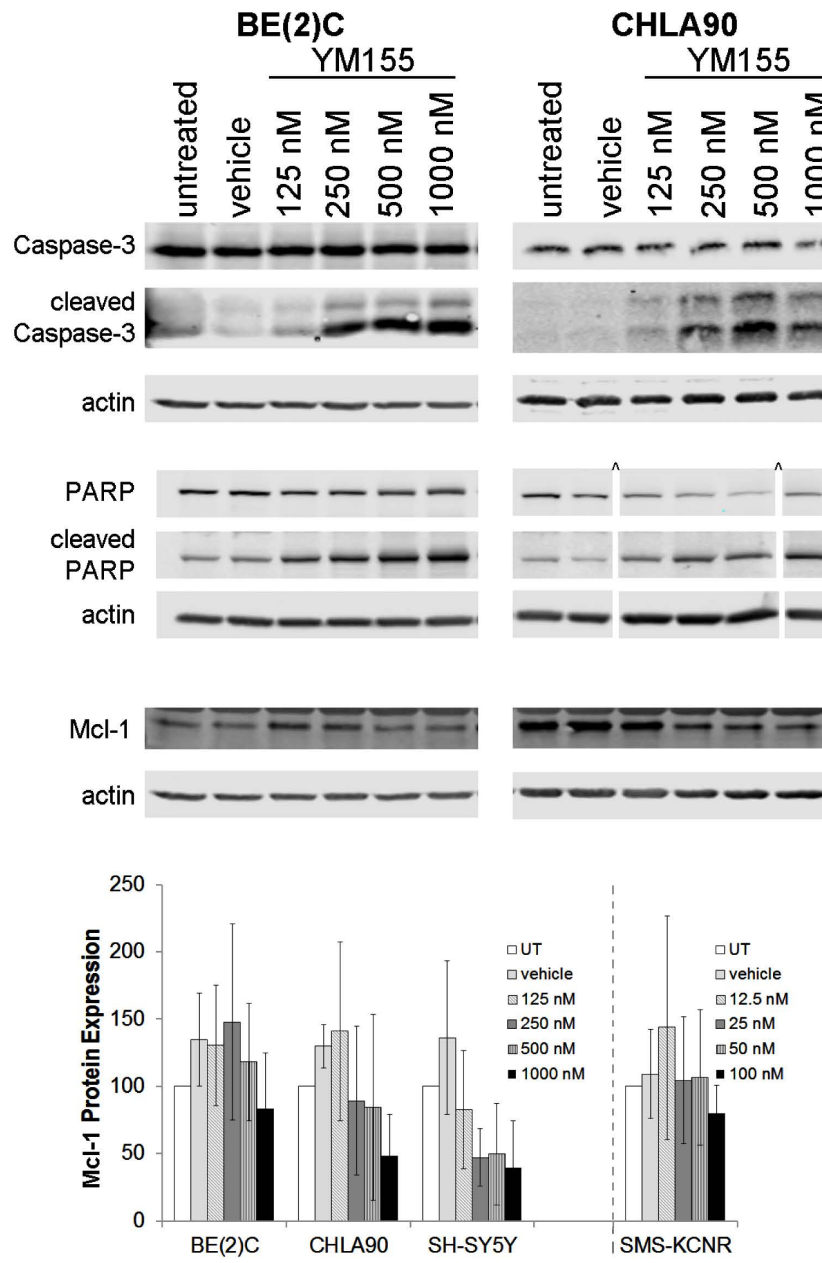

(c)

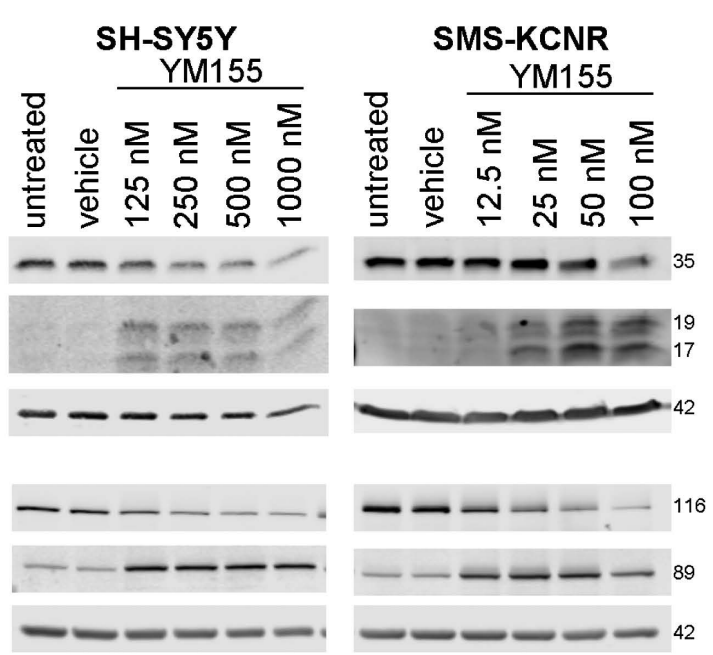

(a)

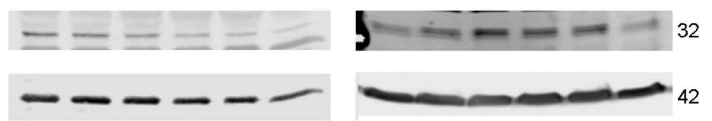

(b)

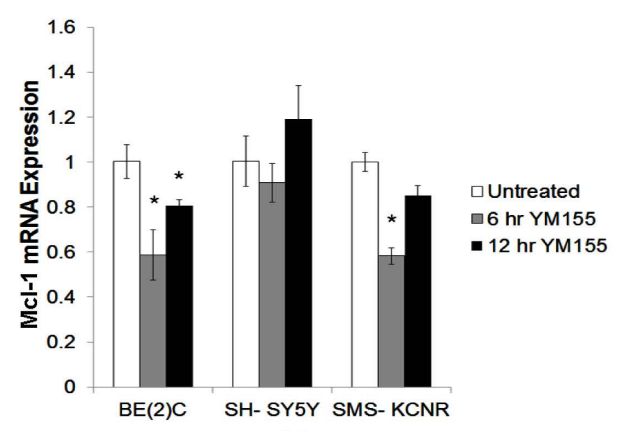

(d)

Figure 3. YM155 induces signaling for apoptosis. (a) Western blot analyses indicate increased caspase-3 and PARP cleavage in neuroblastoma cells exposed to YM155 for $48 \mathrm{hr}$; (b) Western blot analysis shows decreased expression of Mcl-1 protein with 48 hr YM155 treatment; (c) Quantitation of Mcl-1 protein confirms decreased expression; (d) YM155 reduced expression Mcl-1 transcript at $6 \mathrm{hr}$ in BE(2)C and SMS-KCNR cells, but with little or no change in expression at $12 \mathrm{hr}$. *Significantly different from untreated cells $\mathrm{p} \leq 0.042$. Quantitation represents $n=3$ experiments and representative blots are shown. ^Bands were moved from a different part of the same blot. 
confirmed reduced Mcl-1 protein expression following $48 \mathrm{hr}$ treatment with YM155 despite a slight induction by the vehicle (Figure 3(b) and quantitated in Figure 3(c)). qPCR (Figure 3(d)) shows decreased Mcl-1 expression in BE(2)C and SMS-KCNR at $6 \mathrm{hr}$ (250 nM and $50 \mathrm{nM}$, respectively), but then expression recovers at $12 \mathrm{hr}$ after YM155 treatment, returning to the level found in untreated cells for SMS-KCNR. Expression in SY5Y was unchanged at any time point (Figure 3(d)) and no consistent changes in expression in CHLA90 were observed (data not shown). These data suggest that YM155 may have an indirect effect on Mcl-1 protein expression in neuroblastoma cells.

\subsection{YM155 Alters Expression of Genes Involved in Migration and Apoptosis}

Microarray analysis of BE(2)C cells indicated that YM155 treatment decreased expression of survivin (Table 2). YM155 treatment did not significantly change expression of other IAP proteins (data not shown); however, examination of other genes involved in migration and survival signaling showed a change in expression. Table 2 shows genes involved in apoptosis and/or migration, for which expression was changed by $>1.5$-fold following $12 \mathrm{hr}$ exposure to YM155. Like Mcl-1, the effects of YM155 on expression of genes such as TGM2 (Transglutaminase 2) that promote cell survival [42] may aid in the anti-tumor effects of YM155. Many of the genes identified promote cell migration including CDC25A (Cell Division Cycle 25A), CXCR4 (Chemokine Receptor 4), zyxin (ZYX), ephrin-B1 (EFNB1), and a disintegrin and metalloproteinase with thrombospondin motifs-1 (ADAMTS1) [43]-[48]. Treatment with YM155 reduced the expression of most of these genes, either directly or indirectly, suggesting that these pathways may be involved in the inhibition of migration by YM155.

Table 2. YM155 induces changes in expression of genes involved in migration and apoptosis. BE(2)C cells were treated \pm YM155 (250 nM) for $12 \mathrm{hr}$. Microarray analysis of treated versus untreated cells identified several genes involved in apoptosis and/or migration signaling pathways for which expression is significantly changed by YM155. Twenty genes with the greatest change in expression for migration and apoptosis pathways are shown.

\begin{tabular}{|c|c|c|}
\hline Gene symbol & Fold change & $\mathrm{p}$-value \\
\hline BIRC5 & -2.97295 & $1.15 \mathrm{E}-6$ \\
\hline SDC1 & -2.87152 & $5.63 \mathrm{E}-4$ \\
\hline CDC25A & -2.68777 & 0.002826 \\
\hline TGM2 & -2.47326 & $2.55 \mathrm{E}-3$ \\
\hline EFNB1 & -2.06959 & 0.008898 \\
\hline MGAT5 & -2.06326 & 0.000155 \\
\hline ADRB2 & -1.98096 & 0.006454 \\
\hline CD44 & -1.94873 & 0.001243 \\
\hline ADAMTS1 & -1.72508 & 0.004316 \\
\hline CXCR4 & -1.66986 & 0.010546 \\
\hline MSX2 & 1.87647 & 0.005905 \\
\hline ZYX & 2.10436 & $9.41 \mathrm{E}-4$ \\
\hline KALRN & 2.18131 & $3.49 \mathrm{E}-4$ \\
\hline FMN1 & 2.49372 & $1.27 \mathrm{E}-5$ \\
\hline PTPRH & 2.53891 & $3.02 \mathrm{E}-3$ \\
\hline FNBP1 & 2.8294 & $1.09 \mathrm{E}-4$ \\
\hline ID1 & 2.90711 & $8.00 \mathrm{E}-8$ \\
\hline SMAD6 & 3.1044 & $5.80 \mathrm{E}-5$ \\
\hline ARHGEF2 & 4.15769 & $2.49 \mathrm{E}-5$ \\
\hline ATF5 & 6.69577 & $1.30 \mathrm{E}-7$ \\
\hline
\end{tabular}




\subsection{YM155 Reduces Tumor Growth and Metastasis in Vivo}

Xenografts of SMS-KCNR and BE(2)C cells were used to assess the effects of YM155 on tumor growth in vivo. Seven day treatment with YM155 (5 or $10 \mathrm{mg} / \mathrm{kg}$ ) reduced tumor volume of SMS-KCNR tumors (Figure 4(a)). Tumors of BE(2)C cells demonstrated a slight reduction in tumor volume with YM155 treatment, however, statistical significance was not achieved (Figure 4(b)). As there was little difference in tumor volumes between the doses of 5 and $10 \mathrm{mg} / \mathrm{kg}$ in the above experiments, animals were treated with 2 and $5 \mathrm{mg} / \mathrm{kg}$ YM155 for the assessment of overall survival in SMS-KCNR-inoculated mice. Results indicate that at $2 \mathrm{mg} / \mathrm{kg}$, YM155 prolongs survival in vivo by 33\% (Figure 4(c)).

To determine whether YM155 could inhibit metastasis in vivo, DNA was isolated from livers and lungs of tumor-bearing mice. The level of human DNA present in the tissues was measured by qPCRas described in [49]. Expression of human Alu normalized to mouse GAPDH indicated that YM155 inhibited metastasis to liver by 50\% (Figure 4(d)). YM155 had no effect on metastasis to lungs (data not shown).

\section{Discussion}

Recent evidence that suggests that survivin promotes migration in several cancers [20]-[23] [28]. Increased survivin expression in neuroblastoma correlates with high-risk group, which is also characterized by metastasis

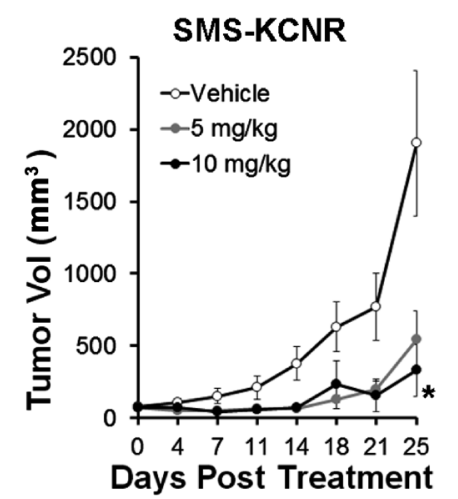

(a)

SMS-KCNR

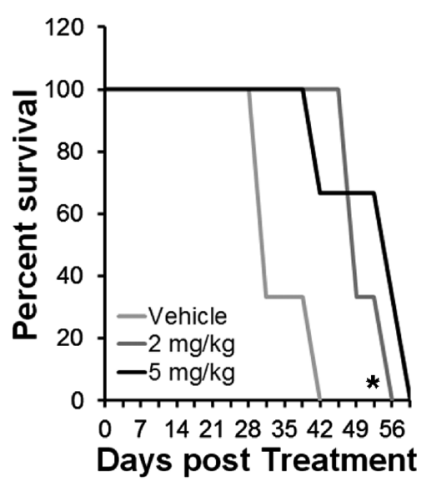

(c)

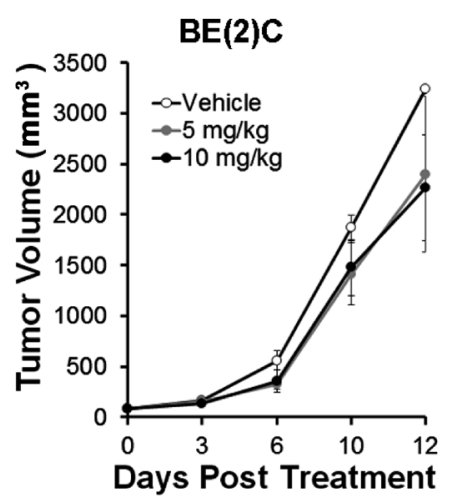

(b)
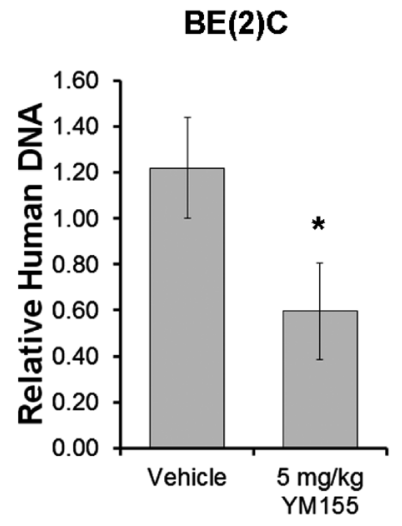

(d)

Figure 4. YM155 inhibits tumor growth and metastasis in vivo. Nude mice, harboring subcutaneous xenograft tumors of (a) and (c) SMS-KCNR cells or BBE(2)C cells were treated with YM155 or saline (vehicle) by osmotic pump on days 0-7. Tumor volume was measured twice weekly. (a) and (b) Results indicate that YM155 inhibits tumor growth in vivo; (c) Mice were euthanized as each tumor reached $3000 \mathrm{~mm}^{3}$; (d) Human DNA (Alu) in the livers of mice inoculated with BE(2)C tumors was measured by qPCR. Data indicate human Alu relative to mouse GAPDH and reflect three mice per group. Results indicate that YM155 slows tumor growth, prolongs survival, and inhibits metastasis to liver in vivo. $\mathrm{p} \leq 0.024$. 
[24]. This led us to investigate the effects of YM155 treatment on neuroblastoma cell migration and invasion. For these studies lower, non-cytotoxic concentrations of YM155 were used in order to reduce any confounding effects on cell proliferation and/or apoptosis. The effects of YM155 on migration and invasion are evident in the more resistant $\mathrm{BE}(2) \mathrm{C}$ cells, where invasion is inhibited by nearly $50 \%$ (Figure 2(d)). This is consistent with the decrease in metastasis observed for BE(2)C cells in vivo (Figure 4(d)). BE(2)C cells were resistant to YM155 in viability assays, but exhibited sensitivity in cell migration experiments, suggesting that patients whose tumors are resistant to the apoptotic effects of YM155 may still benefit from treatment with YM155 to inhibit metastasis.

To gain additional insight into migration inhibition by YM155, expression of genes involved in migration were examined after YM155 treatment. Several genes that promote metastasis are downregulated by YM155. CXCR4 has been implicated in neuroblastoma metastasis to bone marrow [43]. CD44 expression promotes metastasis in many cancers. In neuroblastoma, however, loss of CD44 did not inhibit cells from leaving the primary tumor, but slowed tumor growth at the metastatic site, resulting in micrometastases [50]. Other genes such as SMAD6, a negative regulator of transforming growth factor-beta (TGF-b) signaling [51], are involved in cell migration as well as survival. Further analysis of these genes will give insight into the mechanism by which YM155 inhibits metastasis in neuroblastoma.

Neuroblastoma cell lines exhibit a wide range of sensitivities to YM155 (Figure 1(d) and [18]). In our studies, sensitivity did not correlate with MYCN (Table 1) or p53 status (data not shown). Lamers et al., [18] determined that resistance is correlated with expression of the multidrug transporter ABCB1. Indeed, sensitivity of our cell lines to YM155 correlates with ABCB1 expression (Table 1). However, while BE(2)C had the highest ABCB1 expression of all the cell lines tested and was resistant at $48 \mathrm{hr}$, YM155 suppressed survivin mRNA at 6 $\mathrm{hr}$, and suppressed survivin protein and induced apoptotic signaling at $48 \mathrm{hr}$. When exposure to YM155 was increased from 48 to $72 \mathrm{hr}, \mathrm{BE}(2) \mathrm{C}$ cells showed much greater sensitivity (Figure 1(d)).

Assessment of apoptosis signaling (Figure 3(a)) confirmed that YM155 induces programmed cell death in neuroblastoma cells. Evidence that YM155 inhibits expression of Mcl-1 [14]-[16] and that Mcl-1 is upregulated and confers chemoresistance in neuroblastoma [1] [17] prompted us to examine the effects of YM155 on Mcl-1 in neuroblastoma cells. Our data indicate that the observed decrease in Mcl-1 expression is not likely to be a direct effect of YM155, as the effect on RNA expression was transient, but was sustained at the protein level. YM155 can induce protein ubiquitination [15]. This may be aYM155-mediated mechanism for loss of Mcl-1 protein. In a recent study, ectopic expression of survivin in IMR32 neuroblastoma cells caused only a partial rescue from YM155-induced apoptosis [18]. YM155-mediated decrease in Mcl-1 may account for the additional effects observed for YM155 on neuroblastoma apoptosis. However, further investigation is required to establish the relationship between the effects on Mcl-1 and cell death in these cells.

In vivo, YM155 has demonstrated anti-tumor activity in multiple cancer types, including neuroblastoma [12] [29]-[33]. Sensitivities of the cell lines to YM155 in vivo correlated with cell viability in vitro. SMS-KCNR tumor model experienced significantly reduced tumor growth (Figure 4(a)), while BE(2)C tumors showed a only mild decrease in tumor growth following YM155 treatment (Figure 4(b)). In addition, we determined that YM155 reduces metastases in the livers of mice harboring BE(2)C tumors. Our models suggest that patients with tumors that are more sensitive to YM155 will benefit most from the pro-apoptotic effects, whereas patients whose tumors are more resistant may still benefit from the anti-metastatic effects following de-bulking and/or in combination with other therapies. Indeed, recent reports have indicated that YM155 sensitizes cancers to chemotherapies [29] [31] [33] [34]-[36], targeted therapies [30] [32] [37], and natural compounds [28].

\section{Conclusion}

In conclusion, YM155 is effective in inhibiting neuroblastoma tumor growth, migration, and metastatic burden suggesting that YM155 may be a promising adjuvant treatment for neuroblastoma.

\section{Acknowledgements}

The authors are grateful to the Andrew McDonough B+ Foundation and the Beat NB Foundation for their support of this research, Astellas Pharma for generously providing YM155 for these studies, Drs. Jeff MacKeigan and Vanessa Fogg for use of the microscope and assistance with the wound assay, Andrew Borgman for consultation on statistical analyses, Dr. Jeff Bond and Julie Dragon for training and assistance with expression analyses, 
and Drs. Sandra Rempel, Stacey Thomas, Andre Bachman, and Lorenzo Sempere for critical analysis of the manuscript.

\section{Conflict of Interest}

The authors have no conflicts to report.

\section{References}

[1] Maris, J.M., Hogarty, M.D., Bagatell, R. and Cohn, S.L. (2007) Neuroblastoma. Lancet, 369, 2106-2120. http://dx.doi.org/10.1016/S0140-6736(07)60983-0

[2] Owens, C. and Irwin, M. (2012) Neuroblastoma: The Impact of Biology and Cooperation Leading to Personalized Treatments. Critical Reviews in Clinical Laboratory Sciences, 49, 85-115. http://dx.doi.org/10.3109/10408363.2012.683483

[3] American Cancer Society (2012) Cancer Facts and Figures. Atlanta.

[4] Wagner, L.M. and Danks, M.K. (2009) New Therapeutic Targets for the Treatment of High-Risk Neuroblastoma. Journal of Cellular Biochemistry, 107, 46-57. http://dx.doi.org/10.1002/jcb.22094

[5] Maris, J.M. (2010) Recent Advances in Neuroblastoma. New England Journal of Medicine, 362, 2202-2211. http://dx.doi.org/10.1056/NEJMra0804577

[6] Yoon, K.J. and Danks, M.K. (2009) Cell Adhesion Molecules as Targets for Therapy of Neuroblastoma. Cancer Biology \& Therapy, 8, 306-311. http://dx.doi.org/10.4161/cbt.8.4.7446

[7] Ambros, P.F., Ambros, I.M., Brodeur, G.M., Haber, M., Khan, J., Nakagawara, A., Schleiermacher, G., Speleman, F., Spitz, R., London, W.B., et al. (2009) International Consensus for Neuroblastoma Molecular Diagnostics: Report from the International Neuroblastoma Risk Group (INRG) Biology Committee. British Journal of Cancer, 100, 1471-1482. http://dx.doi.org/10.1038/sj.bjc.6605014

[8] Islam, A., Kageyama, H., Takada, N., Kawamoto, T., Takayasu, H., Isogai, E., Ohira, M., Hashizume, K., Kobayashi, H., Kaneko, Y. and Nakagawara, A. (2000) High Expression of Survivin, Mapped to 17q25, Is Significantly Associated with Poor Prognostic Factors and Promotes Cell Survival in Human Neuroblastoma. Oncogene, 19, 617-623. http://dx.doi.org/10.1038/sj.onc.1203358

[9] Lamers, F., van der Ploeg, I., Schild, L., Ebus, M.E., Koster, J., Hansen, B.R., Koch, T., Versteeg, R., Caron, H.N. and Molenaar, J.J. (2011) Knockdown of Survivin (BIRC5) Causes Apoptosis in Neuroblastoma via Mitotic Catastrophe. Endocrine-Related Cancer, 18, 657-668. http://dx.doi.org/10.1530/ERC-11-0207

[10] Yamauchi, T., Nakamura, N., Hiramoto, M., Yuri, M., Yokota, H., Naitou, M., Takeuchi, M., Yamanaka, K., Kita, A., Nakahara, T., et al. (2012) Sepantronium Bromide (YM155) Induces Disruption of the ILF3/p54(nrb) Complex, Which Is Required for Survivin Expression. Biochemical and Biophysical Research Communications, 425, 711-716. http://dx.doi.org/10.1016/j.bbrc.2012.07.103

[11] Cheng, Q., Ling, X., Haller, A., Nakahara, T., Yamanaka, K., Kita, A., Koutoku, H., Takeuchi, M., Brattain, M.G. and Li, F. (2012) Suppression of Survivin Promoter Activity by YM155 Involves Disruption of Sp1-DNA Interaction in the Survivin Core Promoter. International Journal of Biochemistry and Molecular Biology, 3, 179-197.

[12] Nakahara, T., Kita, A., Yamanaka, K., Mori, M., Amino, N., Takeuchi, M., Tominaga, F., Kinoyama, I., Matsuhisa, A., Kudou, M. and Sasamata, M. (2011) Broad Spectrum and Potent Antitumor Activities of YM155, a Novel SmallMolecule Survivin Suppressant, in a Wide Variety of Human Cancer Cell Lines and Xenograft Models. Cancer Science, 102, 614-621. http://dx.doi.org/10.1111/j.1349-7006.2010.01834.x

[13] Nakahara, T., Takeuchi, M., Kinoyama, I., Minematsu, T., Shirasuna, K., Matsuhisa, A., Kita, A., Tominaga, F., Yamanaka, K., Kudoh, M. and Sasamata, M. (2007) YM155, a Novel Small-Molecule Survivin Suppressant, Induces Regression of Established Human Hormone-Refractory Prostate Tumor Xenografts. Cancer Research, 67, 8014-8021. http://dx.doi.org/10.1158/0008-5472.CAN-07-1343

[14] Tang, H.K., Shao, H., Yu, C. and Hou, J.S. (2011) Mcl-1 Downregulation by YM155 Contributes to Its Synergistic Anti-Tumor Activities with ABT-263. Biochemical Pharmacology, 82, 1066-1072. http://dx.doi.org/10.1016/j.bcp.2011.07.064

[15] Na, Y.S., Yang, S.J., Kim, S.M., Jung, K.A., Moon, J.H., Shin, J.S., Yoon, D.H., Hong, Y.S., Ryu, M.H., Lee, J.L., et al. (2012) YM155 Induces EGFR Suppression in Pancreatic Cancer Cells. PLoS ONE, 7, e38625. http://dx.doi.org/10.1371/journal.pone.0038625

[16] Feng, W., Yoshida, A. and Ueda, T. (2013) YM155 Induces Caspase-8 Dependent Apoptosis through Downregulation of Survivin and Mcl-1 in Human Leukemia Cells. Biochemical and Biophysical Research Communications, 435, 52-57. http://dx.doi.org/10.1016/j.bbrc.2013.04.036 
[17] Lestini, B.J., Goldsmith, K.C., Fluchel, M.N., Liu, X., Chen, N.L., Goyal, B., Pawel, B.R. and Hogarty, M.D. (2009) Mcl1 Downregulation Sensitizes Neuroblastoma to Cytotoxic Chemotherapy and Small Molecule Bcl2-Family Antagonists. Cancer Biology \& Therapy, 8, 1587-1595. http://dx.doi.org/10.4161/cbt.8.16.8964

[18] Lamers, F., Schild, L., Koster, J., Versteeg, R., Caron, H.N. and Molenaar, J.J. (2012) Targeted BIRC5 Silencing Using YM155 Causes Cell Death in Neuroblastoma Cells with Low ABCB1 Expression. European Journal of Cancer, 48, 763-771. http://dx.doi.org/10.1016/j.ejca.2011.10.012

[19] Lladser, A., Sanhueza, C., Kiessling, R. and Quest, A.F. (2011) Is Survivin the Potential Achilles’ Heel of Cancer? Advances in Cancer Research, 111, 1-37. http://dx.doi.org/10.1016/B978-0-12-385524-4.00001-5

[20] Mehrotra, S., Languino, L.R., Raskett, C.M., Mercurio, A.M., Dohi, T. and Altieri, D.C. (2010) IAP Regulation of Metastasis. Cancer Cell, 17, 53-64. http://dx.doi.org/10.1016/j.ccr.2009.11.021

[21] McKenzie, J.A., Liu, T., Goodson, A.G. and Grossman, D. (2010) Survivin Enhances Motility of Melanoma Cells by Supporting Akt Activation and $\alpha 5$ Integrin Upregulation. Cancer Research, 70, 7927-7937. http://dx.doi.org/10.1158/0008-5472.CAN-10-0194

[22] Hingorani, P., Dickman, P., Garcia-Filion, P., White-Collins, A., Kolb, E.A. and Azorsa, D.O. (2013) BIRC5 Expression Is a Poor Prognostic Marker in Ewing Sarcoma. Pediatric Blood \& Cancer, 60, 35-40. http://dx.doi.org/10.1002/pbc.24290

[23] Ghadimi, M.P., Young, E.D., Belousov, R., Zhang, Y., Lopez, G., Lusby, K., Kivlin, C., Demicco, E.G., Creighton, C.J., Lazar, A.J., et al. (2012) Survivin Is a Viable Target for the Treatment of Malignant Peripheral Nerve Sheath Tumors. Clinical Cancer Research, 18, 2545-2557. http://dx.doi.org/10.1158/1078-0432.CCR-11-2592

[24] Miller, M.A., Ohashi, K., Zhu, X., McGrady, P., London, W.B., Hogarty, M. and Sandler, A.D. (2006) Survivin mRNA Levels Are Associated with Biology of Disease and Patient Survival in Neuroblastoma: A Report from the Children's Oncology Group. Journal of Pediatric Hematology/Oncology, 28, 412-417. http://dx.doi.org/10.1097/01.mph.0000212937.00287.e5

[25] Ito, R., Asami, S., Motohashi, S., Ootsuka, S., Yamaguchi, Y., Chin, M., Shichino, H., Yoshida, Y., Nemoto, N., Mugishima, H. and Suzuki, T. (2005) Significance of Survivin mRNA Expression in Prognosis of Neuroblastoma. Biological and Pharmaceutical Bulletin, 28, 565-568. http://dx.doi.org/10.1248/bpb.28.565

[26] Eslin, D., Lee, C., Sankpal, U.T., Maliakal, P., Sutphin, R.M., Abraham, L. and Basha, R. (2013) Anticancer Activity of Tolfenamic Acid in Medulloblastoma: A Preclinical Study. Tumor Biology, 34, 2781-2789. http://dx.doi.org/10.1007/s13277-013-0836-6

[27] Obexer, P., Hagenbuchner, J., Unterkircher, T., Sachsenmaier, N., Seifarth, C., Bock, G., Porto, V., Geiger, K. and Ausserlechner, M. (2009) Repression of BIRC5/Survivin by FOXO3/FKHRL1 Sensitizes Human Neuroblastoma Cells to DNA Damage-Induced Apoptosis. Molecular Biology of the Cell, 20, 2041-2048. http://dx.doi.org/10.1091/mbc.E08-07-0699

[28] Hossain, M.M., Banik, N.L. and Ray, S.K. (2012) Survivin Knockdown Increased Anti-Cancer Effects of (-)-Epigallocatechin-3-Gallate in Human Malignant Neuroblastoma SK-N-BE2 and SH-SY5Y Cells. Experimental Cell Research, 318, 1597-1610. http://dx.doi.org/10.1016/j.yexcr.2012.03.033

[29] Mir, R., Stanzani, E., Martinez-Soler, F., Villanueva, A., Vidal, A., Condom, E., Ponce, J., Gil, J., Tortosa, A. and Gimenez-Bonafe, P. (2014) YM155 Sensitizes Ovarian Cancer Cells to Cisplatin Inducing Apoptosis and Tumor Regression. Gynecologic Oncology, 132, 211-220. http://dx.doi.org/10.1016/j.ygyno.2013.11.013

[30] Kaneko, N., Kita, A., Yamanaka, K. and Mori, M. (2013) Combination of YM155, a Survivin Suppressant with a STAT3 Inhibitor: A New Strategy to Treat Diffuse Large B-Cell Lymphoma. Leukemia Research, 37, 1156-1161. http://dx.doi.org/10.1016/j.leukres.2013.05.010

[31] Kaneko, N., Yamanaka, K., Kita, A., Tabata, K., Akabane, T. and Mori, M. (2013) Synergistic Antitumor Activities of Sepantronium Bromide (YM155), a Survivin Suppressant, in Combination with Microtubule-Targeting Agents in Triple-Negative Breast Cancer Cells. Biological and Pharmaceutical Bulletin, 36, 1921-1927. http://dx.doi.org/10.1248/bpb.b13-00515

[32] Kita, A., Mitsuoka, K., Kaneko, N., Nakata, M., Yamanaka, K., Jitsuoka, M., Miyoshi, S., Noda, A., Mori, M., Nakahara, T. and Sasamata, M. (2012) Sepantronium Bromide (YM155) Enhances Response of Human B-Cell Non-Hodgkin Lymphoma to Rituximab. Journal of Pharmacology and Experimental Therapeutics, 343, 178-183. http://dx.doi.org/10.1124/jpet.112.195925

[33] Liang, H., Zhang, L., Xu, R. and Ju, X.L. (2013) Silencing of Survivin Using YM155 Induces Apoptosis and Chemosensitization in Neuroblastomas Cells. European Review for Medical and Pharmacological Sciences, 17, $2909-2915$.

[34] Iwasa, T., Okamoto, I., Takezawa, K., Yamanaka, K., Nakahara, T., Kita, A., Koutoku, H., Sasamata, M., Hatashita, E., Yamada, Y., et al. (2010) Marked Anti-Tumour Activity of the Combination of YM155, a Novel Survivin Suppressant, and Platinum-Based Drugs. British Journal of Cancer, 103, 36-42. http://dx.doi.org/10.1038/sj.bjc.6605713 
[35] Kumar, B., Yadav, A., Lang, J.C., Cipolla, M.J., Schmitt, A.C., Arradaza, N., Teknos, T.N. and Kumar, P. (2012) YM155 Reverses Cisplatin Resistance in Head and Neck Cancer by Decreasing Cytoplasmic Survivin Levels. Molecular Cancer Therapeutics, 11, 1988-1998. http://dx.doi.org/10.1158/1535-7163.MCT-12-0167

[36] Yoon, D.H., Shin, J.S., Jin, D.H., Hong, S.W., Jung, K.A., Kim, S.M., Hong, Y.S., Kim, K.P., Lee, J.L., Suh, C., et al. (2012) The Survivin Suppressant YM155 Potentiates Chemosensitivity to Gemcitabine in the Human Pancreatic Cancer Cell Line MiaPaCa-2. Anticancer Research, 32, 1681-1688.

[37] Chen, J., Pise-Masison, C.A., Shih, J.H., Morris, J.C., Janik, J.E., Conlon, K.C., Keating, A. and Waldmann, T.A. (2013) Markedly Additive Antitumor Activity with the Combination of a Selective Survivin Suppressant YM155 and Alemtuzumab in Adult T-Cell Leukemia. Blood, 121, 2029-2037. http://dx.doi.org/10.1182/blood-2012-05-427773

[38] Kelly, R.J., Thomas, A., Rajan, A., Chun, G., Lopez-Chavez, A., Szabo, E., Spencer, S., Carter, C.A., Guha, U., Khozin, S., Poondru, S., Van Sant, C., Keating, A., Steinberg, S.M., Figg, W. and Giaccone, G. (2013) A Phase I/II Study of Sepantronium Bromide (YM155, Survivin Suppressor) with Paclitaxel and Carboplatin in Patients with Advanced Non-Small-Cell Lung Cancer. Annals of Oncology, 24, 2601-2606. http://dx.doi.org/10.1093/annonc/mdt249

[39] Tolcher, A.W., Quinn, D.I., Ferrari, A., Ahmann, F., Giaccone, G., Drake, T., Keating, A. and de Bono, J.S. (2012) A Phase II Study of YM155, a Novel Small-Molecule Suppressor of Survivin, in Castration-Resistant Taxane-Pretreated Prostate Cancer. Annals of Oncology, 23, 968-973. http://dx.doi.org/10.1093/annonc/mdr353

[40] Gautier, L., Cope, L., Bolstad, B.M. and Irizarry, R.A. (2004) Affy-Analysis of Affymetrix GeneChip Data at the Probe Level. Bioinformatics, 20, 307-315. http://dx.doi.org/10.1093/bioinformatics/btg405

[41] Samal, K., Zhao, P., Kendzicky, A., Yco, L.P., McClung, H., Gerner, E., Burns, M., Bachmann, A.S. and Sholler, G. (2013) AMXT-1501, a Novel Polyamine Transport Inhibitor, Synergizes with DFMO in Inhibiting Neuroblastoma Cell Proliferation by Targeting both Ornithine Decarboxylase and Polyamine Transport. International Journal of Cancer, 133, 1323-1333. http://dx.doi.org/10.1002/ijc.28139

[42] Fu, J., Yang, Q.Y., Sai, K., Chen, F.R., Pang, J.C., Ng, H.K., Kwan, A.L. and Chen, Z.P. (2013) TGM2 Inhibition Attenuates ID1 Expression in CD44-High Glioma-Initiating Cells. Neuro-Oncology, 15, 1353-1365. http://dx.doi.org/10.1093/neuonc/not079

[43] Zhang, L., Yeger, H., Das, B., Irwin, M.S. and Baruchel, S. (2007) Tissue Microenvironment Modulates CXCR4 Expression and Tumor Metastasis in Neuroblastoma. Neoplasia, 9, 36-46. http://dx.doi.org/10.1593/neo.06670

[44] Crosswell, H.E., Dasgupta, A., Alvarado, C.S., Watt, T., Christensen, J.G., De, P., Durden, D.L. and Findley, H.W. (2009) PHA665752, a Small-Molecule Inhibitor of c-Met, Inhibits Hepatocyte Growth Factor-Stimulated Migration and Proliferation of c-Met-Positive Neuroblastoma Cells. BMC Cancer, 9, 411. http://dx.doi.org/10.1186/1471-2407-9-411

[45] Yamamura, M., Noguchi, K., Nakano, Y., Segawa, E., Zushi, Y., Takaoka, K., Kishimoto, H., Hashimoto-Tamaoki, T. and Urade, M. (2013) Functional Analysis of Zyxin in Cell Migration and Invasive Potential of Oral Squamous Cell Carcinoma Cells. International Journal of Oncology, 42, 873-880.

[46] Feng, X., Wu, Z., Wu, Y., Hankey, W., Prior, T.W., Li, L., Ganju, R.K., Shen, R. and Zou, X. (2011) Cdc25A Regulates Matrix Metalloprotease 1 through Foxo1 and Mediates Metastasis of Breast Cancer Cells. Molecular and Cellular Biology, 31, 3457-3471. http://dx.doi.org/10.1128/MCB.05523-11

[47] Sikkema, A.H., den Dunnen, W.F., Hulleman, E., van Vuurden, D.G., Garcia-Manero, G., Yang, H., Scherpen, F.J., Kampen, K.R., Hoving, E.W., Kamps, W.A., et al. (2012) EphB2 Activity Plays a Pivotal Role in Pediatric Medulloblastoma Cell Adhesion and Invasion. Neuro-Oncology, 14, 1125-1135. http://dx.doi.org/10.1093/neuonc/nos130

[48] Tan Ide, A., Ricciardelli, C. and Russell, D.L. (2013) The Metalloproteinase ADAMTS1: A Comprehensive Review of Its Role in Tumorigenic and Metastatic Pathways. International Journal of Cancer, 133, 2263-2276. http://dx.doi.org/10.1002/ijc.28127

[49] Malek, A., Catapano, C.V., Czubayko, F. and Aigner, A. (2010) A Sensitive Polymerase Chain Reaction-Based Method for Detection and Quantification of Metastasis in Human Xenograft Mouse Models. Clinical \& Experimental Metastasis, 27, 261-271. http://dx.doi.org/10.1007/s10585-010-9324-1

[50] Valentiner, U., Valentiner, F.U. and Schumacher, U. (2008) Expression of CD44 Is Associated with a Metastatic Pattern of Human Neuroblastoma Cells in a SCID Mouse Xenograft Model. Tumor Biology, 29, 152-160. http://dx.doi.org/10.1159/000143401

[51] Santibanez, J.F., Quintanilla, M. and Bernabeu, C. (2011) TGF-Beta/TGF-Beta Receptor System and Its Role in Physiological and Pathological Conditions. Clinical Science, 121, 233-251. http://dx.doi.org/10.1042/CS20110086 


\section{Supplementary}

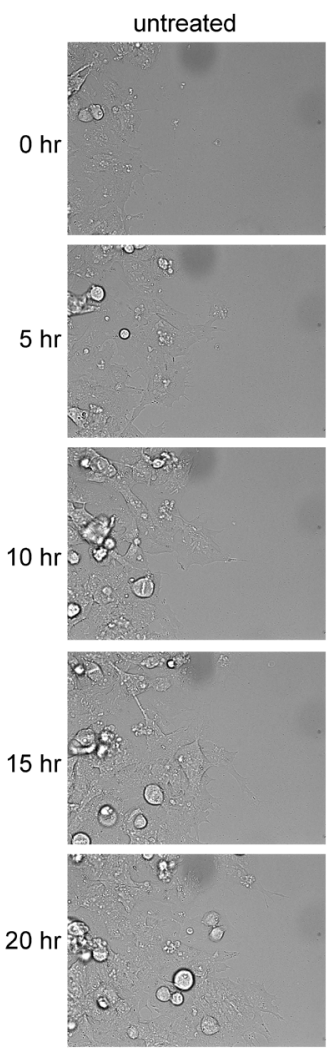

(a)

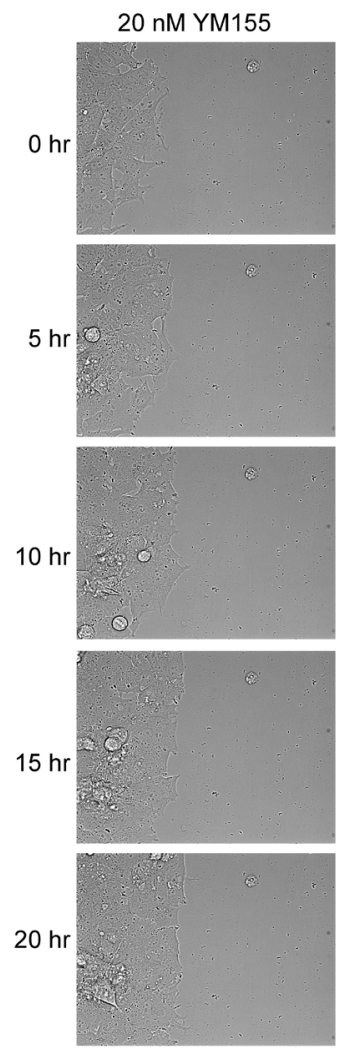

(b)

Figure S1. Cell migration was measured using a wound assay. Representative images show migration of cells at 5 he intervals over $20 \mathrm{hr}$. Untreated cells (left panels) show long projections and migrate further than BE(2)C cells treated with $20 \mathrm{nM}$ YM155 (right panels).
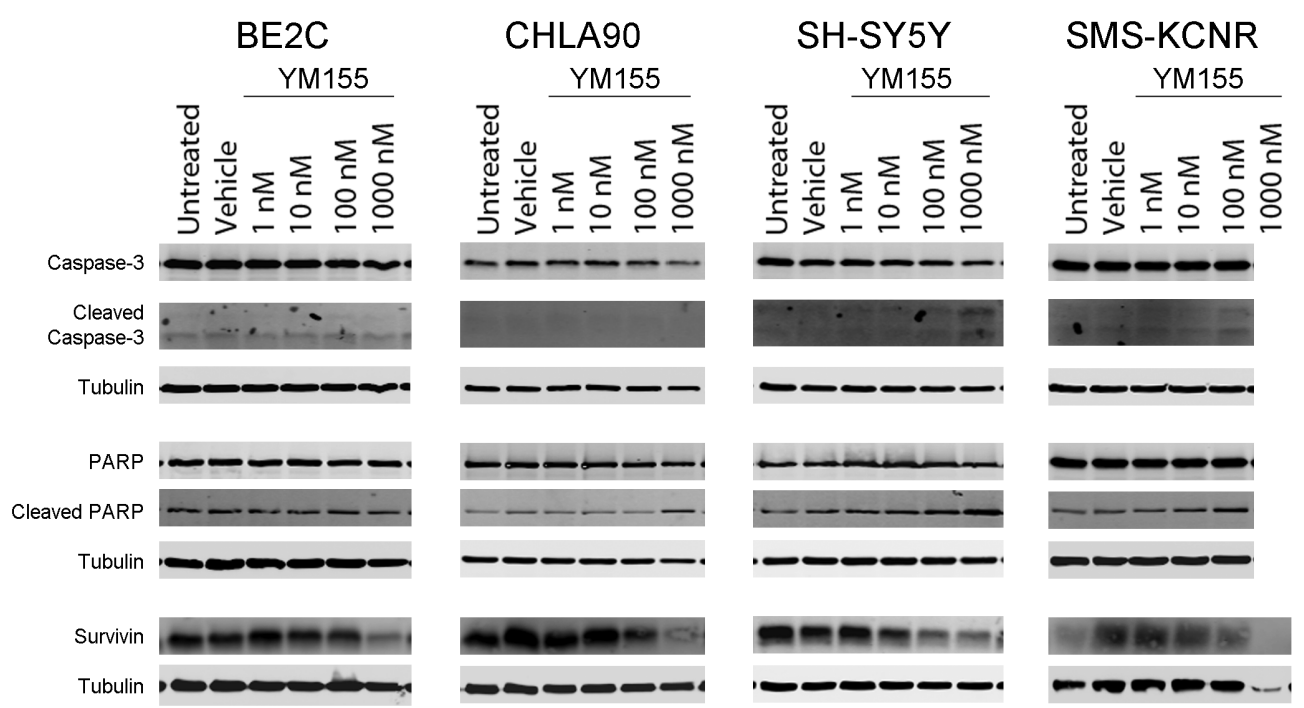

Figure S2. Apoptosis signaling following $24 \mathrm{hr}$ treatment with YM155. Western blot analyses indicate that treatment with YM155 for $24 \mathrm{hr}$ does not induce Caspase-3 or PARP cleavage except at the highest doses shown. Note: SMS-KCNR cells were much more sensitive to YM155 and at $1000 \mathrm{nM}$ there was very little protein present (as shown in the survivin blots), and so this sample was not run on the Caspase- 3 and PARP blots. 
Scientific Research Publishing (SCIRP) is one of the largest Open Access journal publishers. It is currently publishing more than 200 open access, online, peer-reviewed journals covering a wide range of academic disciplines. SCIRP serves the worldwide academic communities and contributes to the progress and application of science with its publication.

Other selected journals from SCIRP are listed as below. Submit your manuscript to us via either submit@scirp.org or Online Submission Portal.
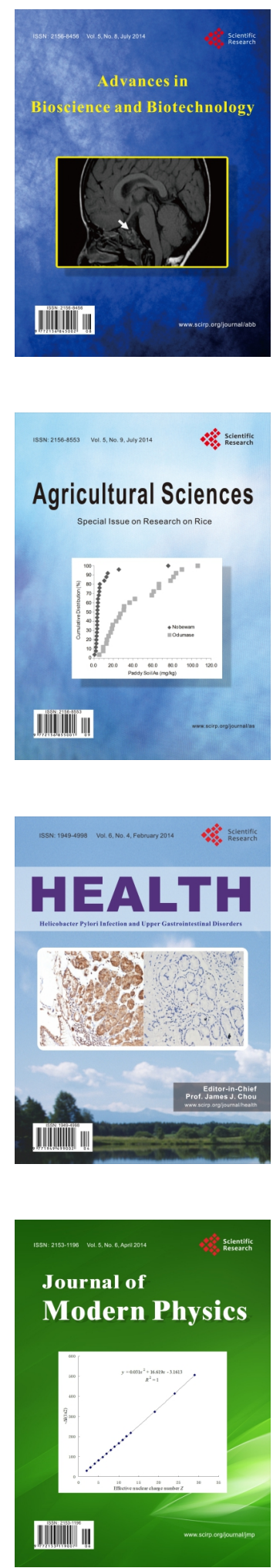
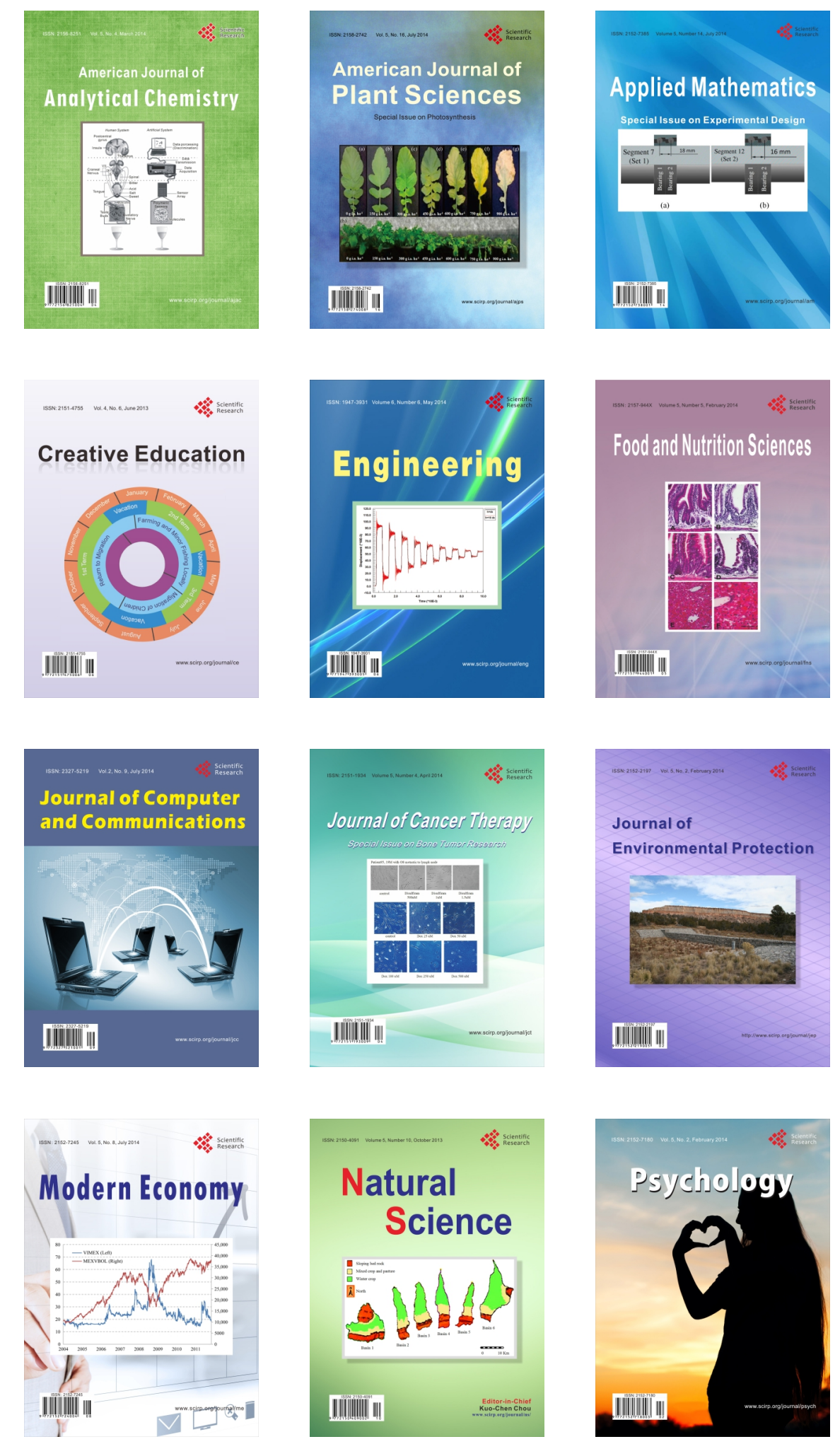